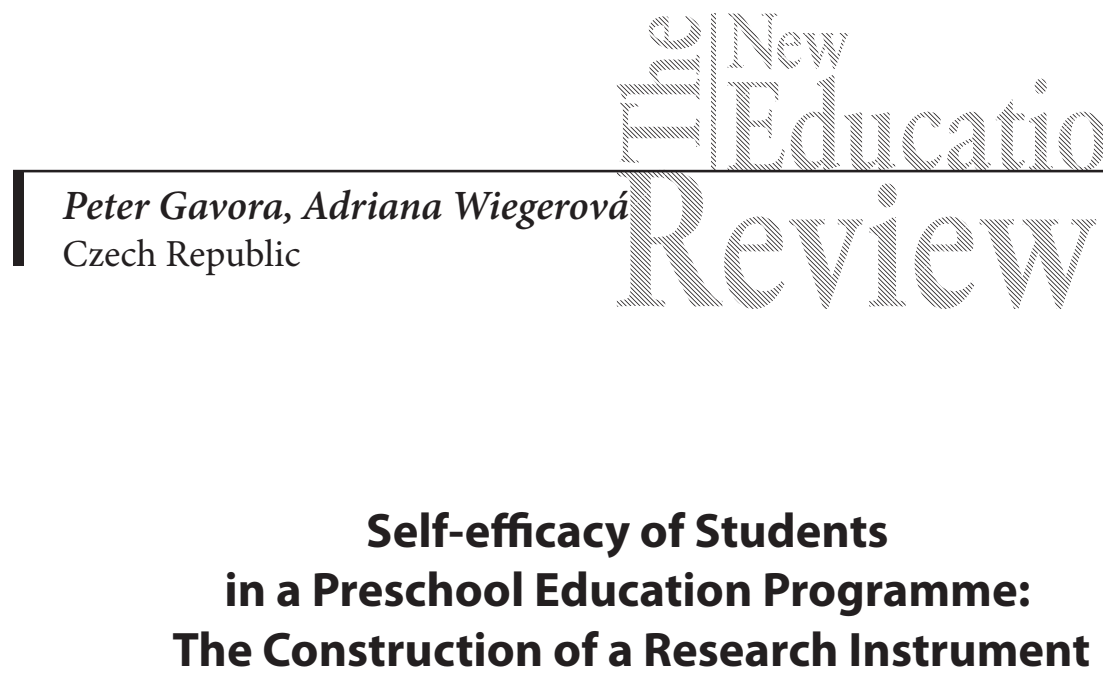

DOI: 10.15804/tner.2017.47.1.10

\begin{abstract}
The primary aim of this article is to present the validation process of the SEPRES questionnaire to measure the self-efficacy of students in a preschool education programme. After the generation of the questionnaire items for the item pool, the items were content validated, and then they underwent an exploratory factor analysis with data from 154 respondents to determine the construct validity of the questionnaire. Four factors were extracted after using Principal axis factoring with Oblimin rotation. The factors are Children involvement, Behaviour elimination, Professional collaboration and Credibility building, and they have Alphas ranging from 0.769 to 0.903 . Inter-correlation among dimensions ranged from 0.419 to 0.681 , indicating that SEPRES is a consistent research instrument.
\end{abstract}

\title{
The Construct of Self-Efficacy
}

Albert Bandura (1986) defines self-efficacy as one's belief in personal qualities that affect the execution of actions to produce desired results. This belief determines how much effort one will invest in an activity, how long one will persevere when faced with an obstacle, how resilient one may be in the face of adversity, whether one's thought patterns are self-aiding or self-hindering, and how the level 
of accomplishments is realized (Pajares, 1996). According to Bandura's theory, self-efficacy has two components: efficacy expectation and outcome expectancy. The former is the conviction that one has the ability, knowledge, and skills to successfully execute the behaviour or actions required to produce the desired outcome(s), while the latter represents a person's estimate of the likely consequences (or impact) of performing a task at the self-expected level of performance.

The construct of teacher efficacy has been an object of extensive research for approximately four decades. Researchers have attempted to assess self-efficacy in the practice of teachers and its impact on pupils' learning. A number of research projects have accumulated evidence about teacher self-efficacy effects in various school situations and environments, ranging from preschool to university. Research has shown that strong teacher efficacy has positive effects on:

- teacher effort and persistence when facing difficulties (Podell \& Soodak, 1993; Gibson \& Dembo, 1984),

- implementing new instructional methods and strategies (Cousins \& Walker, 2000; Evers, Brouwers \& Tomic, 2002),

- pupils' academic achievement and success (Caprara et al., 2006).

Teachers with high levels of self-efficacy:

- are less inclined to job burnout (Aloe, Amo \& Shanahan, 2014),

- usually have more commitment to the profession than other teachers (Tschannen-Moran, Woolfolk Hoy \& Hoy, 1998),

- deal with the needs of low ability pupils (Ross \& Gray, 2006),

- tend to be more open to new ideas (Cousins \& Walker, 2000).

In summary, researchers have successfully demonstrated that the teacher's efficacy beliefs yield higher teacher commitment, larger effort and a strong influence on pupils' outcomes in many areas of education. Efficacious teachers display behaviours which are typical of quality instruction. A highly efficacious teacher does not only believe that the teacher can influence actions but also actually exposes the belief through behaviour.

\section{Measuring Teacher Self-Efficacy}

The prevailing method of investigating teacher self-efficacy is a self-rated questionnaire with Likert-type scales. Respondents indicate their level of confidence in relation to their abilities to teach, which are described in the questionnaire items. Many questionnaires have been developed to measure self-efficacy of pre-service and in-service teachers, but two of them have played an influential role in 
self-efficacy research. Based on Bandura's theory and the locus of control concept, Gibson and Dembo (1984) developed the Teacher Efficacy Scale (TES) consisting of 30-items which, when factor-analysed, yielded two dimensions: Personal teaching efficacy and General teaching efficacy. Another influential instrument, designed by Tschannen-Moran and Woolfolk Hoy (2001), is the Teachers' Sense of Efficacy Scale (OSTES). It consists of 24 items grouped in three dimensions: Instructional strategies, Classroom management and Pupil engagement. Both TES and OSTES were adopted to be used in countries as diverse as France, Taiwan, Turkey, Israel, Slovakia or the Czech Republic. In addition to self-efficacy for teaching in general curriculum areas, a great number of instruments were developed to measure self-efficacy in particular content domains, e.g., for teaching mathematics (Charalambous, Philippou \& Kyriakides, 2007), science (Cakiroglu, Cakiroglu \& Boone, 2005), chemistry (Enochs, Smith \& Huinker, 2000), or character formation (Milson, 2003).

Studies in a number of countries yielded surprisingly-high scores on the self-efficacy of both pre-service and in-service teachers but brought inconclusive outcomes concerning the factor structures of the research instruments used. This indicates both theoretical and psychometric problems, which can be attributed to several factors. First, self-efficacy is an "elusive construct" (Tschannen-Moran \& Woolfolk Hoy, 2001). Although it is easy to define, it is difficult to capture empirically, thus causing problems with construct validity and sometimes also with the reliability of instruments. Second, these instruments are self-rated scales based on respondents' judgements about their inner qualities. These judgements are subjective projections of one's abilities and may not be a realistic picture of the employment of abilities and skills in real teacher practice. The results are also influenced by context specific factors, such as the demography of samples, the scope and content of respondents' in-service training, their subject areas, etc.

Many researchers saw the solution of the problems with the validity of self-efficacy measurement in developing their own self-efficacy instruments that serve specific needs, are faithful to their theoretical orientation and reflect the specific educational conditions of the country. Such instruments were constructed, e.g., by Seo and Moon (2012), Gau and Hung (2014), and Nikolopoulou and Gialamas (2015).

This study contributes to the methodological dispute of self-efficacy research by constructing a new instrument, which is tailored to the purposes of pre-service teachers of preschool education. Examining the self-efficacy of pre-service teachers who specialize in preschool education is of particular importance for university educators. They need to pay considerable attention to their students' self-efficacy and follow its development throughout university study. University educators 
should be aware of changes in self-efficacy during a university programme and should shape its development. For this purpose, they need to have a valid and reliable instrument to measure self-efficacy.

\section{Research Methodology}

The aim of this article is to present the process of development and validation of an instrument to measure student self-efficacy in a preschool education university programme. We found it important to concentrate on investigating the self-efficacy of students rather than of in-service teachers because we - as university teachers - need knowledge of this important student characteristic so that we can include it in a component of teacher preparation.

This instrument concentrates on the self-efficacy of essential aspects of the class instruction of preschool teachers. However, rather than focussing on specific domains of preschool teaching, like pre-mathematics knowledge and skills, pre-literacy or fine motor skills, it concentrates on self-efficacy across domains, thus providing a general portrayal of student teachers' self-efficacy. The aim was to construct an instrument that has satisfactory psychometric properties and is easy to administer.

\section{The Sample}

The sample consisted of 154 student teachers from two Czech universities (Brno and Zlín), who were enrolled in a three-year bachelor's programme in preschool education. The composition of the sample as regards semesters was as follows: $41.6 \%$ in the first semester, $24 \%$ in the third semester and $34.4 \%$ in the fifth semester. All but 2 student respondents were female. In terms of the demographic characteristics, the sample comprises typical students of preschool education in the Czech Republic.

In the course of the bachelor's programme, the students attended lectures and seminars in educational theory as well as in psychological disciplines. They also had structured field training in a preschool. In the first semester, they had an introduction to preschool life by a director of a preschool; throughout the second semester, they had two-hours daily observations of preschool classes; in the third semester, they had observations concentrated on teaching in specific curriculum areas; in the fourth semester, they were teaching children under the supervision of curriculum area specialists; and in the fifth semester, the students conducted four-week, independent, day-long teaching. 
The questionnaire was administered in November and December 2015 in normal class hours in classrooms. Anonymity was secured by asking students not to write their names on the questionnaire forms.

\section{The Instrument}

For the purpose of this investigation, an instrument was developed to measure the self-efficacy of preschool education student teachers. The instrument, hereafter referred to as SEPRES (initials for Self-Efficacy - Preschool), closely adheres to the principles of self-efficacy measurement suggested by Bandura (2006). The construction of SEPRES underwent several rounds. In the first round, we generated a pool of 100 items, which were derived from three sources: a) literature about preschool teacher successful practices, b) the preschool Framework Programme in the Czech Republic, and c) the authors' experiences in the field.

In the second round, the items were reviewed by three experts in preschool education, who assessed their content validity. More specifically, they rated the relevance and clarity of each item. In this process, 44 items were discarded as either unimportant or confusing. The remaining 55 items were considered relevant for the instrument.

Each item had positing wording written positively and included a six-point scale, with end points of "I have no ability" and "I have a high ability". Examples of items are as follows (translation from Czech):

\begin{tabular}{lllllll}
\hline \multicolumn{1}{c}{ Item wording } & \multicolumn{5}{c}{$\begin{array}{c}\text { I have } \\
\text { no ability a high ability }\end{array}$} \\
\hline to prevent problem behaviour of children & 1 & 2 & 3 & 4 & 5 & 6 \\
\hline to create an emotionally appropriate environment & 1 & 2 & 3 & 4 & 5 & 6 \\
\hline to use creative games with children & 1 & 2 & 3 & 4 & 5 & 6 \\
\hline
\end{tabular}

In the next round of the questionnaire construction, the set of 55 items of SEPRES was factor-analysed using the data of the sample. A factor analysis is a method of data condensation into a relatively small number of factors, which yet explain a large proportion of the total variance of the data (Kline, 2000). Exploratory factor analysis was used to discover the factors within the item set, thus assessing the construct validity of the instrument. At the beginning, the KMO measure and Bartlett's test were computed to assess whether the data were appropriate for the factor analysis. The KMO measure was 0.870 and Bartlett's Chi square was $5028.140 ; \mathrm{df}=1225$, which was significant at a $1 \%$ level. Both indexes yielded favourable results, thus enabling the start of factor analytic computation. 
The next step was to ascertain the method of factor extraction. IBM SPSS offers seven extraction methods. We chose principal axis factoring, which does not require large samples and is tolerant to the normality of data distribution. In setting the number of extracted factors, we used the criteria of the eigenvalue 1 rule and the scree plot. There were twelve factors that exceeded eigenvalue 1 , thus producing too many factors for a meaningful interpretation. The screen plot suggested 3, 4 or 6 factors. Factor extractions were computed with the item loading set at 0.40 , including all three options. The best result was with four factors. In order to achieve the best interpretable factor model, the items were rotated, using Oblimin. The result of the rotation is presented in Table 1. Items with factor loadings below 0.40 and items that cross-loaded are not shown in the table. ${ }^{1}$

Table 1. Factors of SEPRES. Principal axis factoring, Oblimin rotation

\begin{tabular}{|c|c|c|c|c|}
\hline & \multicolumn{4}{|c|}{ Factor } \\
\hline & 1 & 2 & 3 & 4 \\
\hline Item 3 & & 0.664 & & \\
\hline Item 4 & & 0.534 & & \\
\hline Item 5 & & & & $\begin{array}{l}-0.407 \\
\end{array}$ \\
\hline Item 6 & & 0.616 & & \\
\hline Item 10 & & 0.833 & & \\
\hline Item 11 & & 0.772 & & \\
\hline Item 12 & & & & -0.560 \\
\hline Item 14 & 0.553 & & & \\
\hline Item 16 & 0.558 & & & \\
\hline Item 17 & 0.681 & & & \\
\hline Item 18 & 0.541 & & & \\
\hline Item 20 & & & & -0.405 \\
\hline Item 21 & & & 0.511 & \\
\hline Item 22 & 0.414 & & & \\
\hline Item 23 & 0.510 & & & \\
\hline Item 24 & & & & -0.511 \\
\hline Item 27 & 0.608 & & & \\
\hline Item 28 & 0.473 & & & \\
\hline
\end{tabular}

${ }^{1}$ A usual component of the factor analytic procedure is the computation of the total variance explained by the extracted factors. This computation, however, cannot be performed in principal axis factoring. When factors are correlated, as in our case, sums of squared loadings cannot be added to obtain a total variance. 


\begin{tabular}{|c|c|c|c|c|}
\hline & \multicolumn{4}{|c|}{ Factor } \\
\hline & 1 & 2 & 3 & 4 \\
\hline Item 29 & 0.695 & & & \\
\hline Item 30 & 0.630 & & & \\
\hline Item 31 & 0.427 & & & \\
\hline Item 33 & & & & -0.566 \\
\hline Item 34 & & & 0.749 & \\
\hline Item 38 & & & 0.633 & \\
\hline Item 40 & & & 0.552 & \\
\hline Item 42 & & & 0.654 & \\
\hline Item 43 & & & 0.506 & \\
\hline Item 44 & 0.466 & & & \\
\hline Item 47 & & & 0.536 & \\
\hline Item 49 & & & 0.600 & \\
\hline Item 50 & 0.400 & & & \\
\hline Item 51 & & & 0.770 & \\
\hline Item 54 & & 0.637 & & \\
\hline Alpha & 0.903 & 0.859 & 0.886 & 0.769 \\
\hline
\end{tabular}

To sum up the item reduction process, we started with a 100 item pool of which 77 items were discarded in two rounds: 45 in the first and 22 in the second. This proved the contention of DeVellis (2003) that the construction of a scaled questionnaire requires an item pool three or four times larger than is the final questionnaire length. With such a robust item pool, the researcher has enough items to be selected in the subsequent rounds of the analysis to constitute a valid and reliable instrument. The result of our factor analysis was 33 items distributed among four factors.

The first factor was called Children's involvement, and it concentrates on teachers' actions that promote children's engagement in activities. Rather than asking the respondents to rate teaching in domain specific instructions like literacy, mathematics or motor skills, this factor concentrates on more general areas across the teaching domains, such as "Organizing age-appropriate activities" or "Giving children opportunities to express their opinions". The factor has 13 items, with an Alpha of 0.903 .

The second factor was called Behaviour elimination. It concerns the elimination of children's inappropriate behaviour and contains items like "Managing the behaviour of problematic children" or "Managing disturbing children" (6 items, Alpha of 0.859). 
The third factor was called Professional collaboration. It involves teachers' cooperation with professionals such as a psychologist, a speech therapist, and a paediatrician in dealing with children's psychological, social and health problems. It also includes cooperation with colleagues in a preschool concerning professional matters as well as communication with the parents of children who attend the preschool. Moreover, the factor contains items concerning the teacher's collaboration with parents. The factor has items such as "Communicating with a psychologist if problems occur with a child", "Cooperating with colleagues in the construction of the preschool curriculum" and "Communicating with parents patiently" (9 items, Alpha of 0.886 ).

The fourth factor was called Credibility building. It concerns the establishment of confidence and trust of children in the teacher by creating a pleasant and harmless climate in the preschool. It consists of items like "Creating a safe environment" or "Being fair to children" (5 items, Alpha of 0.769).

The four factors provide a strong theoretical justification for the construct validity of the questionnaire. They represent a good profile of the teacher's activities, both focused on children (factors 1,2 and 4) and on colleagues and parents with whom they collaborate (factor 3 ). The respondents' judgements of their self-efficacy in class teaching (factors 1,2 and 4) and beyond the class (factor 3) are therefore a good approximation of their beliefs across these areas.

Further evidence of the construct validity of the questionnaire was provided by examining the inter-correlations among dimensions ${ }^{2}$ (Table 2). All dimensions are positively correlated, with medium to high coefficients. ${ }^{3}$ This indicates that the respondents' self-efficacy in the four dimensions is associated, creating a consistent system. Self-efficacy in Children's involvement and in Credibility building yielded the highest correlation (0.681), indicating that they are most closely linked. Indeed, the teacher's approach to children must be persuasive and must attract them so that they are engaged in cooperation with both the teacher and their classmates.

An almost equally high correlation was between self-efficacy in Children's involvement and Professional collaboration (0.631), indicating a close relationship in the respondents' belief to act successfully in these two domains.

2 From this point on, we refer to the factors extracted from the factor analysis as "dimensions of the questionnaire" rather than "factors", as we are moving now beyond the factor analysis.

3 According to the guidelines by Cohen (1988) and Hemphill (2003), a correlation coefficient size between 0.30 and 0.50 is considered medium, while above 0.50 is considered large. 
Self-efficacy in Children's involvement was moderately positively correlated with self-efficacy in bad Behaviour elimination (0.491). This relation is defendable on the grounds that if the teacher is strong in managing the children's learning activities, then the teacher also has the potential to reduce or eliminate disruptive behaviour.

A high correlation was identified between self-efficacy in negative Behaviour elimination and Credibility building in children (0.562). Again, this is conceptually-suitable evidence. If the teacher believes in their abilities in managing inappropriate behaviour, there is a chance that the same teacher also believes in their capability of building trust in children.

The weakest correlation was identified between self-efficacy in Behaviour elimination and Professional collaboration (0.419), showing a certain link between the teacher's work with a problematic situation in the classroom and professional advice from colleagues and communication with parents.

Overall, the inter-correlations among the factors indicate good convergent validity of the questionnaire. The relationships among factors are theoretically sound, thus supporting the conceptual unity of the questionnaire.

Table 2. Inter-correlations among the dimensions of the SEPRES questionnaire

\begin{tabular}{lccc}
\hline & $\begin{array}{c}\text { Behaviour elimi- } \\
\text { nation }\end{array}$ & $\begin{array}{c}\text { Professional } \\
\text { collaboration }\end{array}$ & Credibility building \\
\hline Children's involvement & 0.491 & 0.631 & 0.681 \\
\hline Behaviour elimination & & 0.419 & 0.562 \\
\hline Professional collaboration & & & 0.546 \\
\hline
\end{tabular}

All correlations are significant at the 0.01 level (2-tailed).

\section{Descriptive Data}

Table 3 presents descriptive results of the dimensions of SEPRES. The averages in all the dimensions are relatively high, exceeding the midpoint of a six-point scale, indicating that the students are quite confident in their potentials to teach in a preschool. Most possibly, they possess an optimistic view of their abilities to organize instruction, manage a class of children and collaborate with colleagues and parents. This optimism may be attributed to a lack of experience with the complexities of educating preschool children. The highest score was obtained in Credibility building. The respondents strongly believe in their abilities to create 
a safe learning environment, support respect among children, and be fair to children. This belief is stronger than that of creating a learning environment that involves children in activities (Involving children), but the difference between the scores of these two dimensions is rather small. The elimination of children's problem behaviour produced the lowest score of the four dimensions, demonstrating that the respondents are aware that this element of teacher behaviour is the most difficult. The respondents scored somewhat lower on the Professional collaboration dimension than on the two other two dimensions of teacher behaviour, i.e., Children's involvement and Credibility building.

Table 3. Descriptive data of the dimensions of SEPRES

\begin{tabular}{lcccc}
\hline & $\mathrm{N}$ & Mean & SD & Skewness \\
\hline Children's involvement & 154 & 4.83 & 0.63 & 0.269 \\
\hline Behaviour elimination & 153 & 3.96 & 0.75 & -0.127 \\
\hline Professional collaboration & 154 & 4.58 & 0.79 & -0.055 \\
\hline Credibility building & 154 & 5.05 & 0.61 & -0.471 \\
\hline
\end{tabular}

Interesting findings were obtained concerning the distribution of scores on SEPRES across semesters of the bachelor's programme. Figure 1 shows two distinct trends. First, self-efficacy scores in each semester reflect the same trend as the scores of the entire sample of respondents. In each semester, the highest score was in Credibility building, followed by Children's involvement and Professional collaboration. The lowest scores were in Behaviour elimination. This consistent

Figure 1. Scores in SEPRES across semesters of the bachelor's pre-school programme

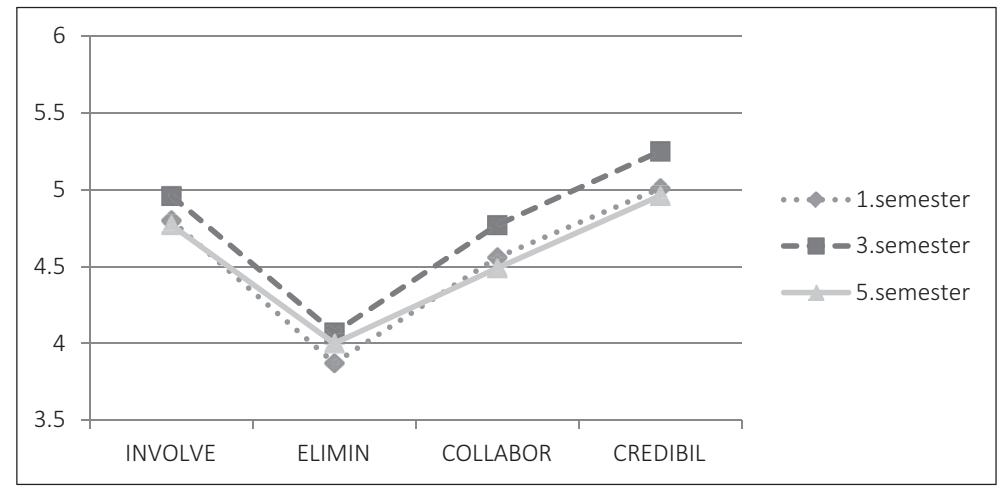


pattern of the scores of the dimensions of SEPRES is another proof of the validity of the questionnaire.

Furthermore, the differences of the scores between the semesters are small, indicating that there is no decisive change in the students' characteristics over the course of the bachelor's programme. We expected a rise in scores each semester due to the increasing competence of the students acquired through lectures, seminars and field practice. This was not confirmed. The most probable explanation is that the students had high self-efficacy already in the first semester, so further increases were improbable in the following semesters.

\section{Discussion}

The primary aim of the article was to present the construction and validation process of the SEPRES questionnaire aimed at measuring the self-efficacy of preschool education students enrolled in a bachelor's programme. After the generation of the questionnaire items for the item pool, the items were content validated and then factor analysed to determine the construct validity of the questionnaire. A four factorial structure, comprising 33 items, was determined to be the best interpretable solution. The factors called Children's involvement, Behaviour elimination, Professional collaboration and Credibility building have satisfactory reliabilities with Cronbach's Alphas ranging from 0.769 to 0.903 . Overall, SEPRES has promising psychometric qualities and can be recommended for the use in other samples of students of preschool education.

Inter-correlations among factors ranged from 0.419 to 0.681 , suggesting that the dimensions are rather closely associated. The finding of close inter-correlations among factors in self-efficacy questionnaires is frequent in other studies, irrespective of the sample (Tschannen-Moran, \& Woolfolk Hoy, 2001; Jamil et al., 2012), on the condition that the dimensions of the questionnaires are based on a single theoretical concept. If a questionnaire is conceptually diverse, inter-factor correlations are small. This is true, for instance, of the TES (Gibson \& Dembo, 1984), which has one factor based on Bandura's concept of self-efficacy and another based on the locus of control theory of J. B. Rotter.

The respondents scored rather high on each of the questionnaire dimensions. Many other studies resulted in a similarly high level of self-efficacy of pre-service teachers, regardless of the construction of the research instrument used, demographic composition of the sample and the country. Consistent results of a high level of self-efficacy of pre-service teachers were obtained, e.g., in the United States 
(Woolfolk Hoy \& Spero, 2005), Turkey (Cakiroglu, Cakiroglu, \& Boone, 2005), Cyprus (Charalambous \& Philippou, 2007), Korea (Seo \& Moon, 2013), and Slovakia (Gavora, 2010). The high scores indicate that students have a rather optimistic view of their abilities to tackle the complexities of the preschool instructional process. This may, however, change after the students enter the preschool profession and are confronted with the everyday duties of full-time teachers.

\section{Conclusions}

According to A. Bandura (1993), self-efficacy determines how people feel, think, behave and motivate themselves, so it is one of the strongest characteristics of teachers. In spite of its importance in teachers' professional development, self-efficacy has been infrequently investigated among preschool teachers (Guo et al., 2011). It has been even less investigated in pre-service preschool teachers. This study contributes to the understanding of how this concept is being developed in a group of pre-service preschool teachers in two Czech universities. For this purpose, a new instrument was developed, SEPRES, the description of the construction of which is the core of this article. The questionnaire showed good validity and reliability and thus may serve as an instrument in other investigations. The authors will provide the instrument to interested colleagues upon request.

\section{References}

Aloe, A.M., Amo, L.C., \& Shanahan, M.E. (2014). Classroom management self-efficacy and burnout. A multivariate meta-analysis. Educational Psychology Review, 26, 101-126. DOI: http://dx.doi.org.10.1007/s10648-013-9244-0.

Bandura, A. (1986). Social foundations of thought and action: A social cognitive theory. Englewood Cliffs, NJ: Prentice-Hall.

Bandura, A. (1993). Perceived self-efficacy in cognitive development and functioning. Educational Psychologist, 28 (2), 117-148.

Bandura, A. (2006). Guide for Constructing Self-Efficacy Scales. In Urban, T., Pajares, F. (eds.) 2006. Self-Efficacy Beliefs of Adolescents. Greenwich, CT: Information Age Publishing, 307-337. ISBN 1-59311-366-8.

Brouwers, A., \& Tomic, W. (2003). A test of the factorial validity of the Teacher Efficacy Scale. Research in Education, 69 (May), 67-79.

Cakiroglu, J., Cakiroglu, E., \& Boone, W. (2005). Pre-service teacher efficacy beliefs regarding science teaching: A comparison of pre-service teachers in Turkey and the USA. Science Educator, 14 (1), 31-40. 
Caprara, G.V., Barbaranelli, C., Steca, P., \& Malone, P.S. (2006).Teachers' self-efficacy beliefs as determinants of job satisfaction and students' academic achievement: A study at the school level. Journal of School Psychology, 44, 473-490.

Charalambous, Y., Philippiou, G., \& Kyriakides, L. (2004). Tracing the development of preservice teachers' efficacy beliefs during fieldwork. Educational Studies in Mathematics (on-line). Available: www.springerlink.com/content/3g043158m382444 (retrieved Nov. 9, 2007).

Cohen, J. (1988). Statistical power analysis for the behavioral sciences ( $2^{\text {nd }}$ ed.). Hillsdale, NJ: Erlbaum.

Cousins, J.B., \& Walker, C.A. (2000). Predictors of educators' valuing of systematic inquiry in schools. Canadian Journal of Program Evaluation, Special Issue, 25-53.

DeVellis, V.R. (2003). Scale development: Theory and application. Thousand Oaks: SAGE.

Enochs, L., Smith, P.L., \& Huinker, D. (2000). establishing factorial validity of the mathematics teaching efficacy beliefs instrument. School Science and Mathematics, 100 (4), 194-202.

Evers, W.J.G., Brouwers, A., \& Tomic, W. (2002). Burnout and self-efficacy: Study on teachers' beliefs when implementing an innovative educational system in the Netherlands. British Journal of Educational Psychology, 72, 227-243.

Gau, B.H., \& Hung, Ch.-Ch. (2014). The Self-Efficacy Scale for preschool teachers regarding asthma care: Instrument development and validation. The Journal of School Health, $84(2), 91-98$.

Gavora, P. (2010). Slovak pre-service teachers self-efficacy: Theoretical and research considerations. The New Educational Review, 21 (2), 17-30.

Gavora, P. (2012). Skúsenosti so zistovaním self-efficacy učitela pomocou dotazníka OSTES. Kvalita ve vzdělávání. Sborník př́íspěvků, XX. výroční konference České asociace pedagogického výzkumu, Praha, 10-12. září 2012.

Gibson, S., \& Dembo, M. (1984). Teacher efficacy: A construct validation. Journal of Educational Psychology, 76 (4), 569-582.

Guo, Y., Justice, L.M., Sawyer, B., \& Tompkins, V. (2011). Exploring factors related to preschool teachers' self-efficacy. Teaching and Teacher Education, 27(5), 961-968.

Hemphill, J.F. (2003). Interpreting the magnitudes of correlation coefficients. American Psychologist, 58 (1), 78-80.

Jamil, F.M., Downer, J.T., \& Pianta, R.C. (2012) Association of pre-service teachers' performance, personality, and belief with teacher self-efficacy at program completion. Teacher Education Quarterly, Fall, 119-138.

Kline, P. (2000). Handbook of psychological testing. Second edition. London: Routlage. ISBN 0-415-21158-1.

Milson, A. (2003). Teachers' sense of efficacy for the formation of students' character. Journal of Research in Character Education, 1 (2), 89-106.

Nikolopoulou, K., \& Gialamas, V. (2015). ICT and play in preschool: early childhood teachers' beliefs and confidence. International Journal of Early Years Education. 23 (4), 409-425. DOI: 10.1080/09669760.2015.1078727. 
pajares, f. (1996). Self-efficacy beliefs in academic settings. Review of Educational Research, $66,543-578$.

Podell, D., \& Soodak, L. (1993). Teacher efficacy and bias in special education referrals. Journal of Educational Research, 86, 247-253.

Ross, J.A., \& Gray, P. (2006). Transformational leadership and teacher commitment to organizational values: The mediating effects of collective teacher efficacy. School Effectiveness and School Improvement, 17 (2), 179-199.

Seo, S., \& Moon, H. (2013). A comparison study of teaching efficacy in pre-service teachers in Korean early childhood education and care (ECEC). Asia-Pacific Journal of Teacher Education, 41(4), 363-373. DOI: 10.1080/1359866X.2013.787394

Tschannen-Moran, M., Woolfolk Hoy, A., \& Hoy, W.K. (1998). Teacher efficacy: its meaning and measure. Review of Educational Research, 68 (2), 202-248.

Tschannen-Moran, M., \& Woolfolk Hoy, A.W. (2001). Teacher efficacy: Capturing an elusive construct. Teaching and Teacher Education, 17 (7), 783-805.

Woolfolk Hoy, A., \& Spero, R.B. (2005). Changes in teacher efficacy during the early years of teaching: A comparison of four measures. Teaching and Teacher Education, 21 (4), 343-356. 